\title{
Iconography of the Procession of Virgins, Chapel of Exodus (Egypt): Origins and Parallels
}

\author{
Valeria Kuvatova \\ Russian Academy of Sciences, Moscow, Russia
}

\begin{abstract}
This study attempts to trace back iconographic origins of an Early Christian scene depicting a procession of women moving towards a temple. The scene makes part of the pictorial program of the so-called Chapel of Exodus-a Coptic mausoleum from Kharga Oasis in Egypt. Never being among the most popular subjects of the Early Christian art, the images of the female processions are found in the monuments throughout the Late Roman Empire, from Roman catacombs to a small house-church at the Eastern border of the Pax Romana (Dura Europos, Syria). The extant scenes are dated back to different periods and belong to the different cultural milieu. The iconographic ambiguity of the procession scene from the Exodus Chapel triggered an intense scholar discussion and gave way to multiple interpretations. Still, the meaning of the episode and the reasons for its inclusion into the pictorial ensemble concept is not quite clear. The study aims to fill these particular gaps in the previous works. The semiotic and contextual analysis allows examining the scene in its relationship with juxtaposed compositions, to compare its iconographic features with descriptions of contemporary religious practices, and clarify the function of the image in the iconographic program of the Chapel of Exodus.

Keywords: Chapel of Exodus, Early Christian painting, Coptic painting, Early Christian art, procession of women
\end{abstract}

Located in the Early Christian necropolis Al Bagawat in the outskirts of Kharga Oasis, the Chapel of Exodus is a small mausoleum covered by a domed vault. The shallow dome accommodates about 20 figurative paintings arranged in two concentric registers around the central zone decorated with a grape wine motif. The painting is loosely dated back to the second half of the 4th through the early 5 th century.

The space over the North-West pylon hosts a scene rather unconventional for the Early Christian funerary art-a procession of seven veiled females, each carrying a torch (or a candle) and a round-shaped vessel (Figure 1). The procession approaches a gabled portico elevated on a seven-step staircase. This type of building is reproduced in the mausoleum paintings in three difference episodes. The image contains an inscription ПАP $\Theta E N O I$ (virgins) made in Greek language. The procession is juxtaposed with two episodes also dedicated to women. The semantic connection between the former and the later remains rather unclear. Above and slightly to the right from the figures of virgins there is a depiction of St. Thekla as an orans on a burning pyre (the caption $\Theta E K \Lambda \mathrm{A}$ is still visible), to the right-an anonymous orans figure staying inside a hill. The unconventional iconography, lack of captions, and obscure relationship among the episodes gave way to a large variety of interpretations.

Valeria Kuvatova, Research Fellow, Institute for Oriental Studies, Russian Academy of Sciences, Moscow, Russia. 


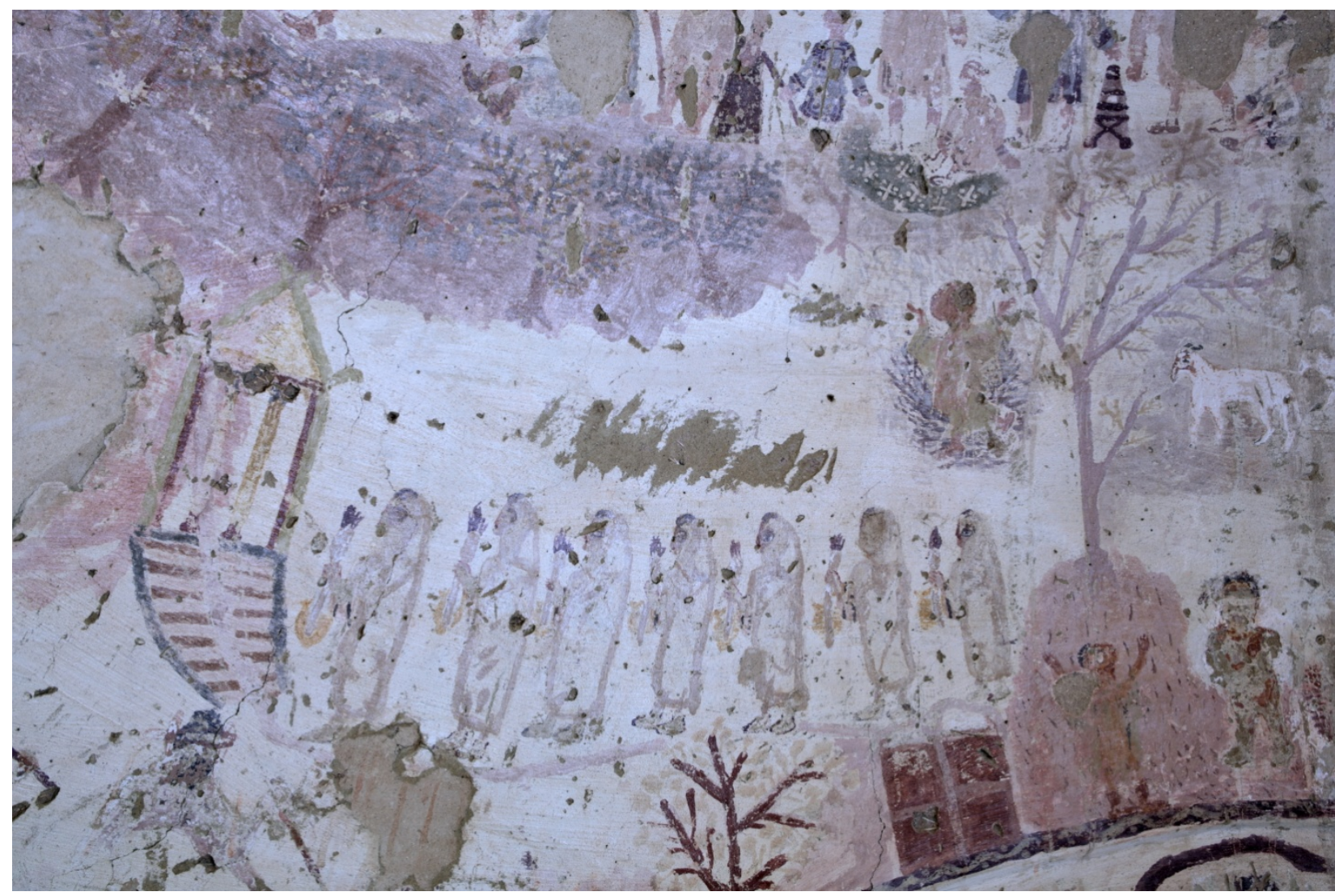

Figure 1. Chapel of Exodus. Procession of Seven Virgins. The author's photo.

V. G. Bock (1901, p. 23), A. Grabar (1956, pp. 9-26), and G. Cipriano (2008, pp. 154-156) attribute the scene to the Parable of the Ten Virgins (Mathew, 25). G. Stern (1960, p. 106) argues that it represents a procession of virgins toward a martyrium or sanctuary dedicated to St. Thekla. According to M. T. Therel's hypothesis (1969, p. 269), lately supported by S. J. Davis (2001, p. 161), the image symbolizes a procession of virgins exiled to Kharga from Alexandria in the course of religious clashes. J. Schwartz associates the composition with the prophecies of Jeremiah and argues that it represents a procession of "sad virgins" from Lamentations, 1:4 (1962, p. 3). M. Zibawi suggests that the scene could be a symbolical illustration to the story of seven virgins, composed by Nilus of Ancyra (Martyrdom of Theodotus of Ancyra and Seven Virgins) (2005, p. 71). M. Martin offers a sophisticated interpretation based on apocryphal description of the procession of virgins who brought young Mary to the temple (Protoevangelium of James, 7:2). He argues that the number of virgins alludes to the menorah (2006, pp. 248-249).

It seems logical to start with ruling out the less plausible assumptions. The interpretation of the episode as a procession of virgins going towards the St. Thekla's martyrium does not seem very convincing. The composition depicting St. Thekla in the burning pyre was painted later than the procession, which is obvious from location of the former between the upper and lower registers and comparative sizes of the figures in both episodes (Figure 2). Moreover, the cloud above Thekla's head overlaps the depiction of landline in the Exodus episode, barely missing the feet of figures in the upper register. Despite the dense arrangement of scenes and obvious deficit of pictorial space, the authors of the wall-paintings usually tried to avoid overlapping the episodes. Having an empty surface instead of the already depicted procession scene, the artist would hardly 
have painted a cloud right over the adjacent composition. As for the alleged image of St. Thekla praying in the rock, it was as well added somewhat later than the procession scene. The outline of the rock (or hill) carefully delineates the foot of the last virgin. Thus, the procession scene could not have been conceived in semantic connection with the orans figure and St. Thekla praying in the burning pyre. The latter two were not part of the original pictorial program of the mausoleum's dome, while the procession was. The alleged connection between the procession scene and the image of Jeremiah standing before Jerusalem seems even more doubtful. The former and the latter are divided by at least two separate compositions. Moreover, the episode with Jeremiah, in my opinion, belongs to the second phase of the pictorial ensemble, while the procession undoubtedly makes part of the initial concept. 


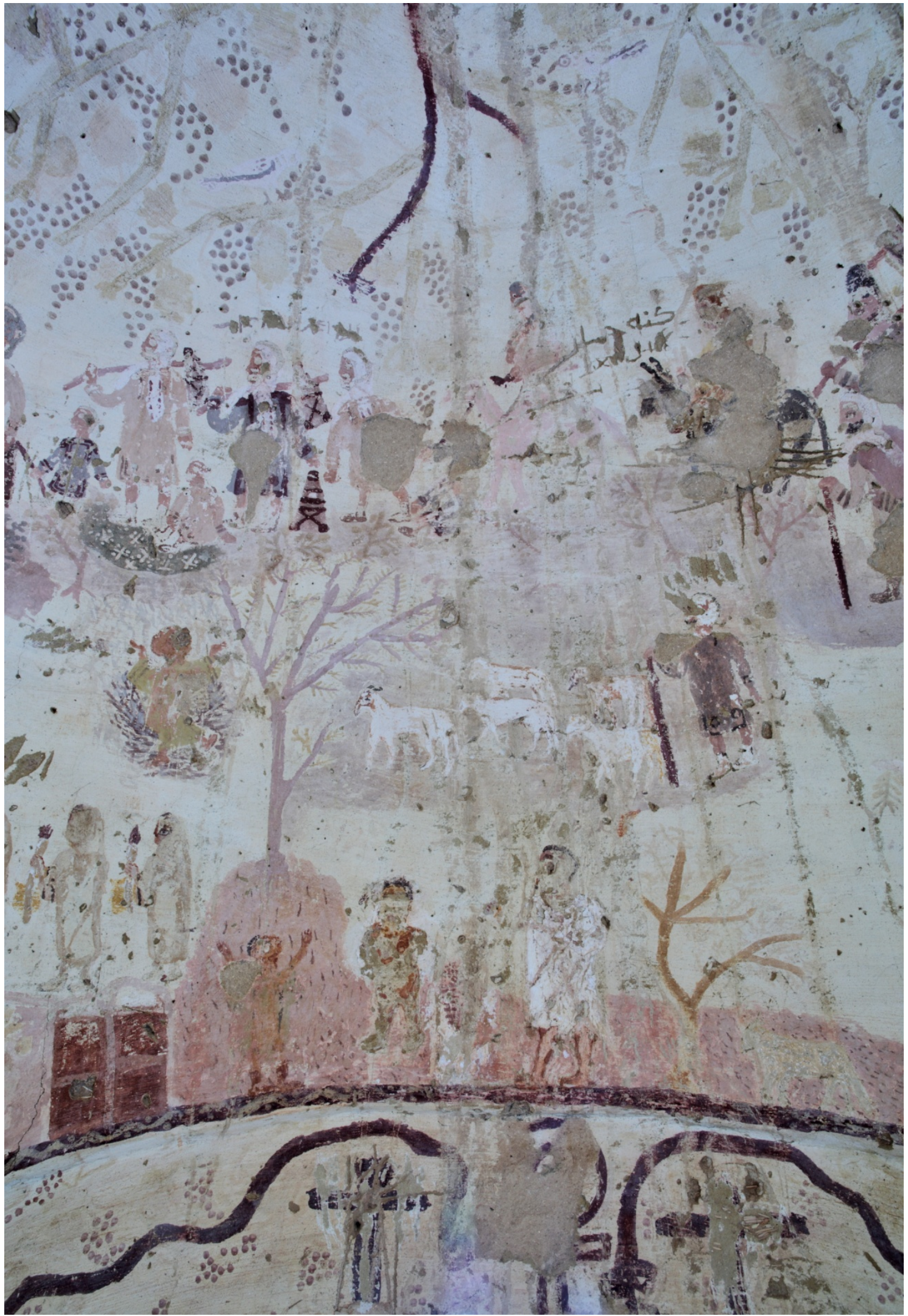

Figure 2. Chapel of Exodus. St. Thekla. The author's photo. 
M.-L. Therel argues that the procession scene is likely to be a representation of Alexandrian virgins exiled to Kharga. This hypothesis assumes that the customers of the painting belonged to Christians expelled from Alexandria during the persecutions of the mid-fifties of the 4th century, inspired by a newly appointed Arian archbishop. This episode is mentioned in Apologia De Fuga Sua of Athanasius of Alexandria ${ }^{1}$. Alexandrian bishops and presbyters, as well as ordinary believers and a group of virgins, were exiled to Kharga oasis. Lacking the additional argumentation, this point of view remains more a guess than a hypothesis. But even if the guess is right, it fails to explain the iconographic features of the scene- the nature of the gabled portico, the number of virgins, and the objects they carry.

M. Martin's hypothesis that the procession scene derives from the story of Presentation of Mary to the Temple can hardly be proved, for nothing in its iconography indicates to this episode. Moreover, the story would have been semantically inconsistent with the iconographic program of the mausoleum.

The hypothesis attributing the episode to the Parable of the Ten Virgins is supported by solid argumentation. The torches and vessels held by the female figures comply with the objects carried by the wise virgins as described in the New Testament. As for the number of virgins, G. Cipriano provides several examples where the number of foolish and wise virgins differs from the Evangelical 10 (2008, p. 155).

Another argument supporting this hypothesis could be added to the mentioned above. The commemorative function of the mausoleum explains the lack of interest in depiction of the foolish virgins, for the Early Christian funerary art focused mainly on salvation paradigm and the happy afterlife. Only the wise women story complies with this paradigm.

But still the reasoning is not conclusive, for the iconography of the procession contains some controversial features, especially the author's concern about the number of virgins. The composition is conspicuously displaced off the central vertical axis of the pylon. From the left it is "pressed out" by the scene of Noah in the Ark. The temple outline is virtually squeezed to the depiction of landmass belonging to the Noah episode. The author still didn't have enough pictorial space for the seven figures, so they gradually turn smaller from left to right and the movement trajectory changes. In order to avoid collision with the landline of the adjacent Sacrifice of Abraham episode, the painter had to move the procession's "tail" slightly up. Bearing in mind the lack of space, it was logical to stick to a fewer number of figures, even more so as five would have complied with the New Testament. But for some reason the artists was determined to paint no less than seven virgins.

The epigraphy accompanying the scene contributes to the uncertainty of its meaning. The only word IIAP $\Theta E N O I$ is not explicative enough to cast aside interpretations other than the Parable of the Ten Virgins. A. Grabar and G. Cipriano suggest a composition on a piece of early Coptic textile from the National Museum of Scotland (Edinburg) as the closest parallel to the episode in the Exodus Chapel. It consists of two couples of female figures flanking the Ethymasia. The torches in the hands of two women are alight; the torches of the other two are dark and turned upside down. The episode includes a caption ПAP $\Theta E N E$ (Grabar, 1956, Fig. 2a-b; Cipriano, 2008). This example, though, is not a complete analogue to the Exodus Chapel depiction. First, its iconography is unequivocal - the figures of the wise and foolish virgins are compositionally divided by the Ethymasia; their torches are differently turned. Second, the textile piece is dated back to the second half of the 5th century, thus, it is substantially younger than the painting. By that time, the repertory and iconographic models of the Early Christian art had attained much more elaborated and sustainable forms and the semantic

${ }^{1}$ Athanasius. Apologia de fuga sua: VI-VII. 
ambiguousness of the initial period had generally been overcome.

The depiction of procession in the Chapel of Exodus contains an unusual feature that does not particularly contribute to its interpretation but rather adds some specific connotations. The earth line behind the virgins rises up the steps of the temple and stops between the columns. It seems to have been important to the author to underscore that the virgins' journey ended actually in the temple.

As for the iconography of the scene, the Panarion of Epiphanius of Salamis provides a description of female procession most consistent with the Exodus Chapel depiction. He introduces a popular Montanist ritual: Often in their church seven virgins enter with torches in white clothes in order to speak prophetically to the people $^{2}$. This description includes most of the specific iconographic features of the scene: Seven female figures dressed in white clothes, torches in their hands, and the temple building.

The amazing correspondence between the painting and the Montanist ritual description does not mean the customers' adherence to the Montanism. More likely, one could assume the existence of some rituals, widely spread throughout the eastern provinces of the Roman Empire, which affected both the Montanist practices and the Exodus Chapel iconography. Epiphanius had never seen the ritual, but his detailed description speaks for its notoriety and expansion. It seems rather safe to assume that the Montanist ritual had derived from some well-established traditions, compatible with the Montanist religious practices.

The question is whether in the 4th century there were some Orthodox rituals that affected the Exodus Chapel iconography. The famous Historia Lausiaca of Palladius, dated back to 419-420, contains descriptions of the everyday routine of Egyptian female congregations and female hermits, but mentions neither female ritual processions nor wearing the white clothes. To the contrary, Palladius underlines the tradition of utmost modesty in term of female clothing ${ }^{3}$. Gregory of Nyssa in his Life of Saint Macrina describes the attitude of the religious female communities to clothes, especially the white ones ${ }^{4}$. In particular, he pictures an episode of Macrina's burial. After her death, her followers dressed her in white clothes, but covered the body with a black cloke, for it was improper for virgins to look at their leader dressed like a bride ${ }^{5}$. Macrina lived in Asia Minor in mid 4th century, which is close to the dating of Exodus Chapel paintings.

So, the study of narrative sources leads to an assumption that the Exodus Chapel iconography was hardly inspired by the contemporary Orthodox rituals. More likely, it derived from some other worship practices that could have existed earlier. The Palmyra reliefs with veiled female figures carrying various objects prove that the tradition of female processions did exist in Eastern provinces of the Roman Empire (Grabar, 1968, p. 46). The Western Roman art provides iconography of vestal processions resembling the Early Christian versions. Moreover, one of the most popular Late Antique goddesses - Isis - is often depicted veiled, dressed in white clothes, with a round-shaped jar in one hand and an object reminding a torch in the other. In Graeco-Roman Egypt it used to be either an Ankh symbol or a sistrum.

M. Zibawi argues that the procession scene could be inspired by the story of seven virgins, described by Nilus of Ancyra in his Life of Saint Theodotus, although the text does not contain any descriptions of processions of women dressed in white (the scholar himself pays attention to this fact (Zibawi, 2005, p. 71)).

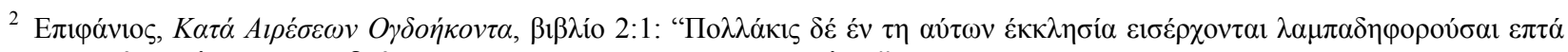

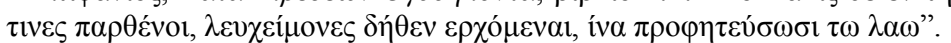

3 Palladius, Historia Lausiaca, XXXIII, XXXIV.

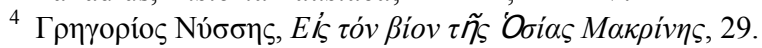

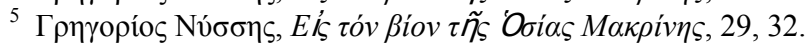


The virgin martyrs were forced to walk naked to the sanctuary of Artemis and were told to put on white priestess' clothes. They rejected the demand and were consequently drowned in the lake (Delehaye, 1903, pp. 320-328). Nevertheless, it does not seem illogical to assume that the Exodus Chapel procession could represent a symbolic description of the story of seven virgins. As M. Zibawi does not offer any arguments supporting his hypothesis, one can add some reasoning. A few features of the story correspond to the Exodus Chapel scene:

- First, when the Christians walk to the lakeshore in order to take away the martyrs' bodies, they follow the light of a miraculous torch shining in the air.

- Second, Theodotus and his companions bring the martyrs' bodies to the temple.

- Third, Nilus of Ankyra repeatedly calls the virgins the brides of Christ, which means that the white clothes would be pertinent.

Thus, the torches in the hands of the women, their white clothes, and the depiction of a temple attain a symbolic meaning. As it is almost impossible to illustrate the legend literary, such symbolic representation seems plausible. The events described by Nilus took place in the first half of the 4th century, so the timing doesn't contradict Zibawi's interpretation of the episode. The legend comes from the region where Montanism gained extreme popularity; therefore, the Montanist rituals were widely spread and well known. Unfortunately, it is impossible to prove any connection between the authors/customers of the painting and Asia Minor.

The iconography of the Exodus Chapel procession invites a comparison to another semantically ambiguous procession from the baptistery of Dura-Europos house-church. Scholars repeatedly stressed the similarity of the two compositions (Millet, 1956, pp. 3-8), in the way the female figures are depicted and the objects they carry, while the number of figures differs. The poor condition of Dura-Europos fresco gave way to various interpretations, depending on whether the scholars include the figures depicted on the adjacent short wall or consider them to belong to a separate scene. Unfortunately, this painting is almost totally destroyed. Only the feet of five women are preserved. The composition is most often interpreted as the mirrophores approaching the Christ tomb. If so, there could have been three figures, while enough empty space remains on the wall for another two. If five figures on the adjacent wall form part of the same episode, the interpretation moves towards the Parable of the Ten Virgins, which is convincingly argued by M. Peppard (2012, pp. 560-563). In this case the total number of personages is reconstructed to 10. At both paintings the female processions move towards some gabled architectural forms. In the mausoleum it looks more like a temple while in the baptistery it reminds a sarcophagus. The Roman temples of this type used to be fairly common in Egypt (Figure 3). 


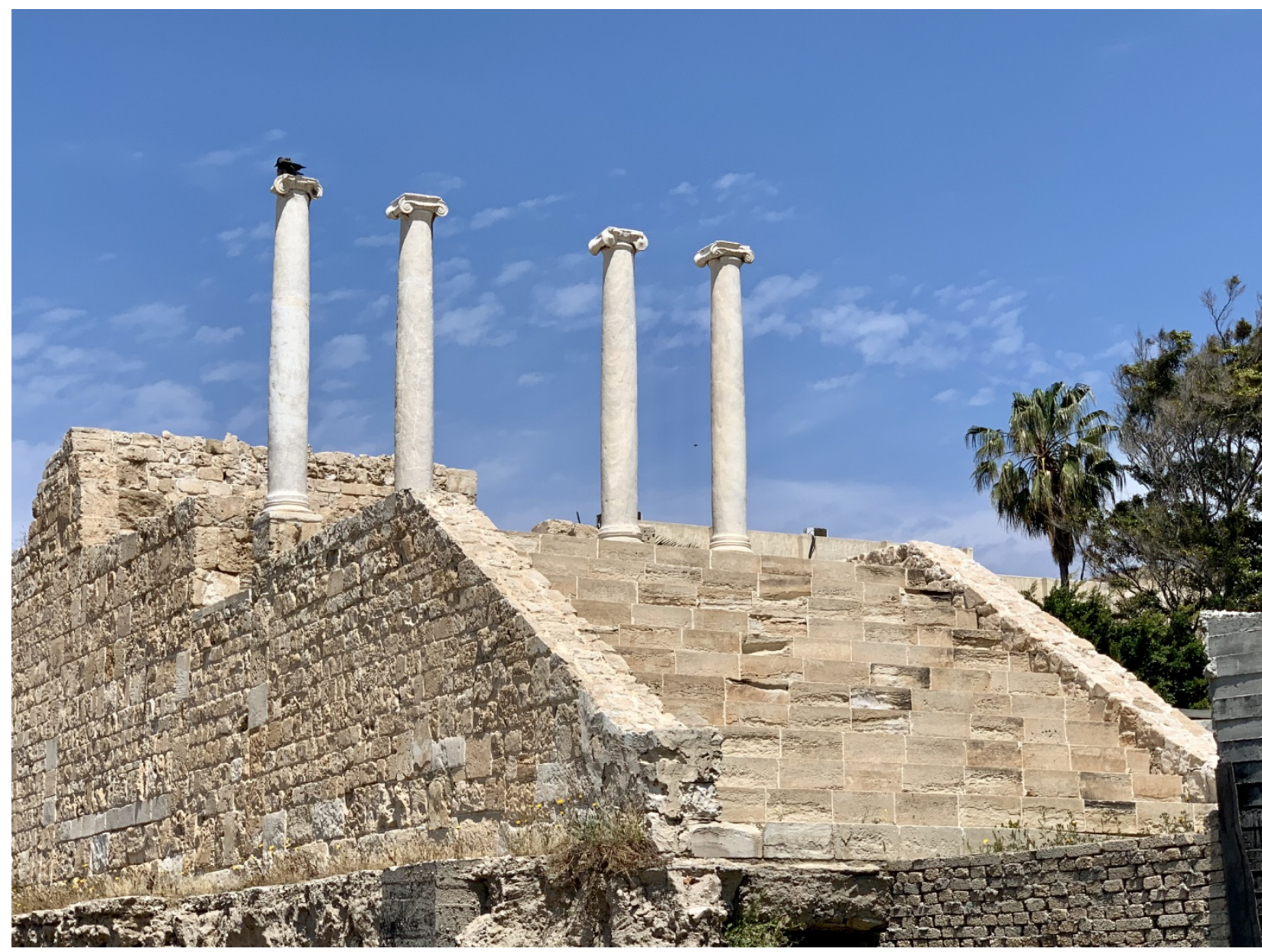

Figure 3. Temple in Alexandria. The author's photo.

Despite the iconographic discrepancies, the two compositions are very much alike, even more so considering the functional difference between the mausoleum and the baptistery. Virgins' processions are rather unconventional in the Early Christian art, thus, the iconographic closeness could hardly be accidental, especially taking into consideration the distance between the two monuments, which is more than $2000 \mathrm{~km}$, while the time gap by far exceeds a century. Some of the popular Old Testament scenes in the Chapel of Exodus (e.g., Adam and Eve in Paradise, Noah in the Ark (Figures 4-5)) show just how much the iconographic interpretation can deviate from the mainstream tradition if the painter lacks a proper sample to copy. All the differences between Kharga and Dura Europos processions do not conceal their similitude. In the meantime, as Persians destroyed Dura Europos in 253 A.D., the immediate influence on Kharga mausoleum is out of the question. Such a similitude might have resulted either from the same subject matter of the two paintings or from the similar visual experience of their authors. The iconographic parallelism of geographically remote monuments often raises a question of once existed and then lost illustrated copies of the Bible. The hypothesis was offered by K. Weitzman (1971, pp. 69-75) and supported, among others, by F. Bisconti (2003, p. 78) and G. Cipriano (2008, p. 163). It is unlikely, though, that having at their disposal an illustrated copy of the Holy Book, the Exodus Chapel authors could not find among the miniatures extremely popular scenes like Noah in the Ark and Adam and Eve in the Paradise. It seems that there were other reasons for such iconographic parallelism. If 
M. Peppard's interpretation of the Dura Europos painting is correct, the two compositions could represent the same Biblical story - the Parable of the Ten Virgins. In this case the differences between them appear even more conspicuous: The number of figures in Dura baptistery complies with the narrative but the sarcophagus-like construction looks rather inappropriate. The architecture of the building depicted in Kharga is likely to be a temple, but the number of figures contradicts the story. The text of the Parable does not mention the white clothes of virgins depicted in both paintings. In the meantime, another Early Christian depiction of the episode (illuminated Rossano Code dated back to the 6 th century $^{6}$ ) also contains this iconographic detail.

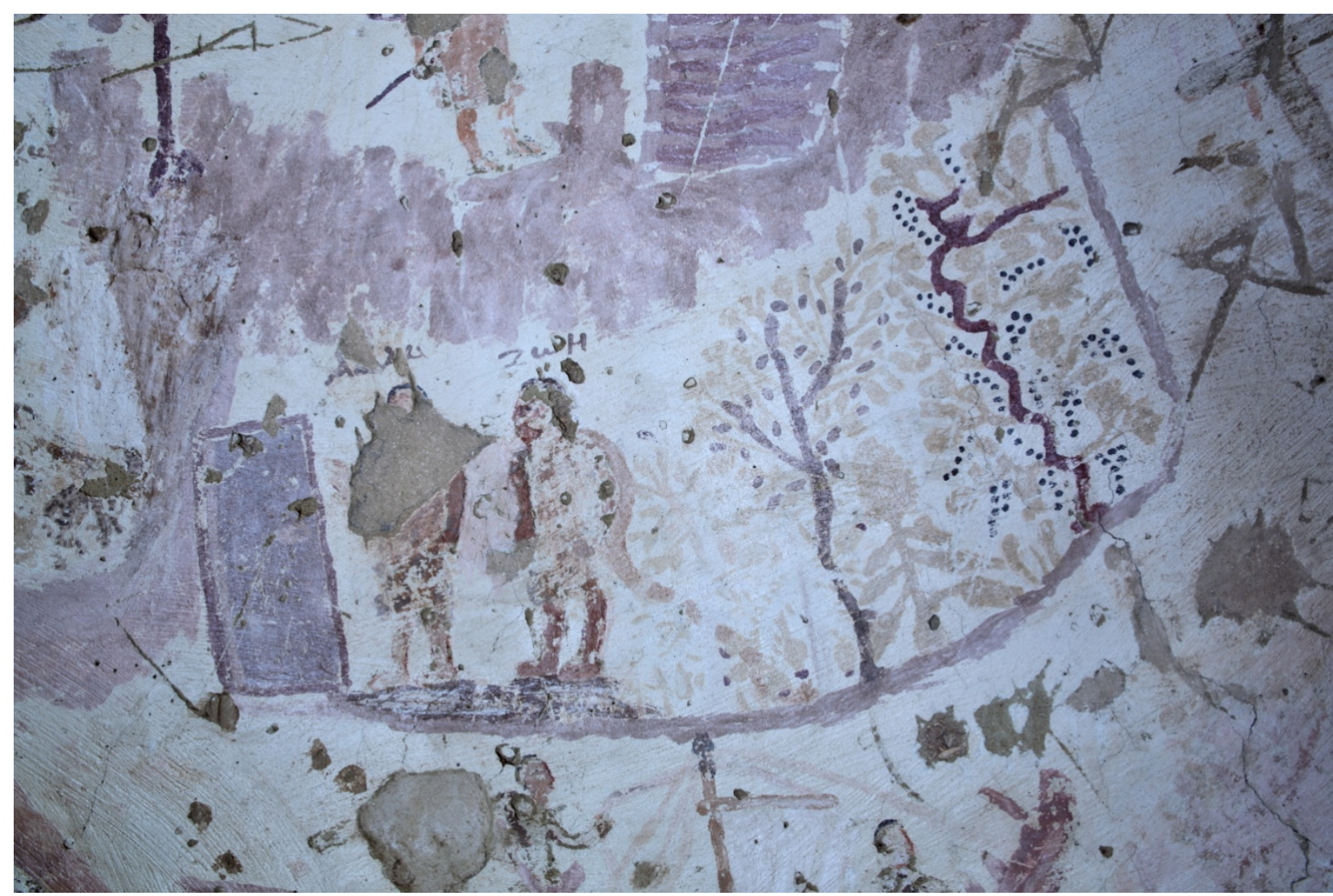

Figure 4. Chapel of Exodus. Adam and Eve in Paradise. The author's photo.

\footnotetext{
${ }^{6}$ Purpureus Rossanensis. Fol. 2v.
} 


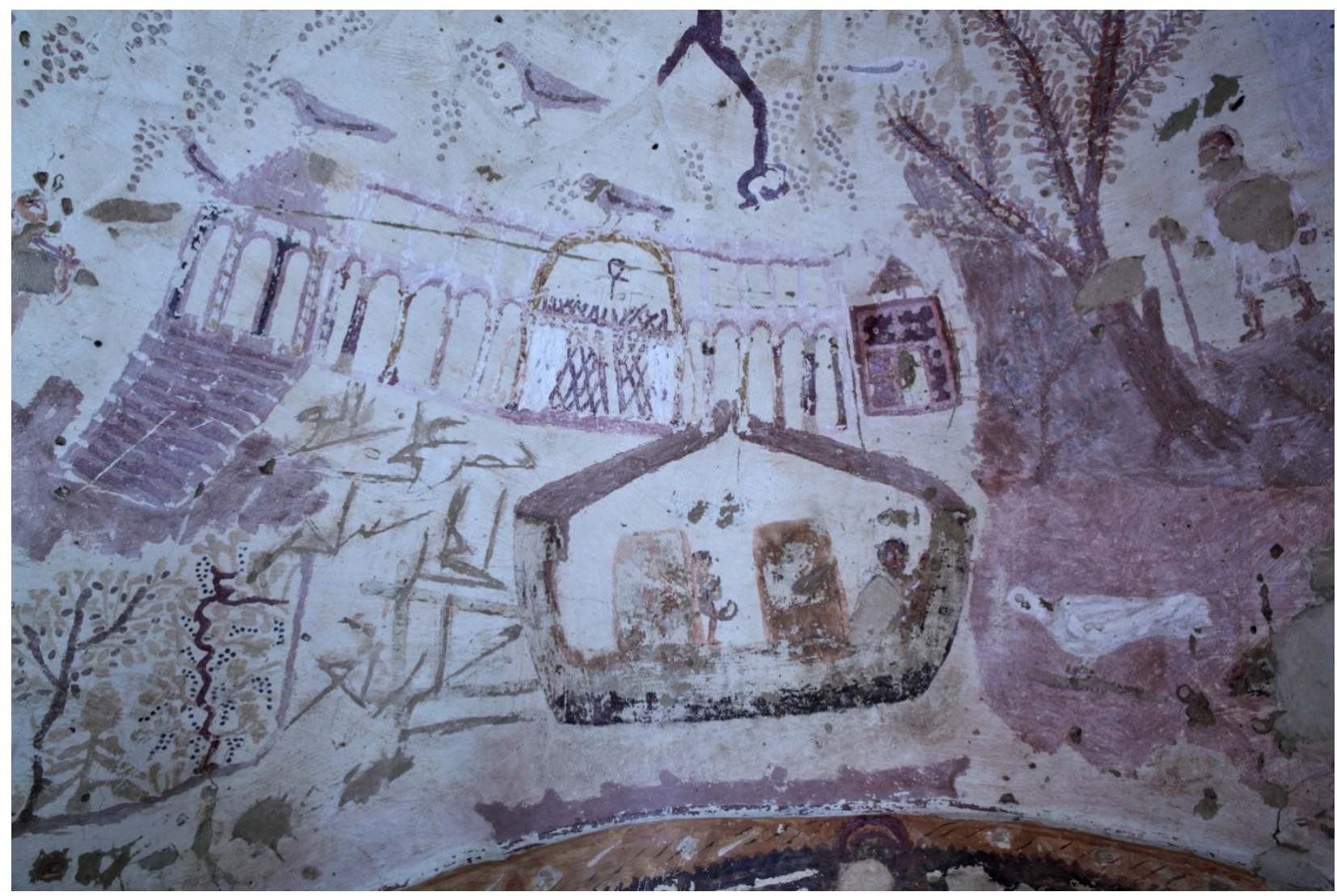

Figure 5. Chapel of Exodus. Noah in the Ark. The author's photo.

The iconographic similarity of the two paintings might not have resulted from the same subject matter, but rather from the same visual experience of the authors, namely some worship practices, popular in the Eastern Mediterranean region. The above-mentioned Montanist ritual could have had the same origins.

The principle question is why the procession scene was included into the iconographic program of the Chapel of Exodus. As it was mentioned, it could not have been conceived in connection with the orans figure and the St. Thekla episode, for the latter two compositions were added after the original program had been fulfilled. However, it seems that the orans and St. Thekla images were juxtaposed with the procession on purpose, in order to set a cluster of episodes based on the gender of the depicted personages. The parallels to this cluster, containing women processions, are scarce in the Early Christian art. Only two pictorial programs can be safely considered as analogous. In the both programs the processions are interpreted as the Parable of the Ten Virgins. The procession depicted in the lunette of an arcosolium in the San Lorenzo catacombs is juxtaposed with an image of deceased woman accompanied by saints (Figure 6). So, the composition makes part of the pictorial program dedicated to a woman. The lunette of an arcosolium in the Coemeterium Maius catacombs is linearly divided into three pictorial spaces. The right one contains a procession of women (Figure 7), the central one - an image of a deceased woman as orans. Thus, the scarce extant funerary iconographic programs, containing depiction of women processions, were dedicated to women. The initial pictorial program of the Exodus Chapel is likely to be dedicated to a woman (or women) as well. 


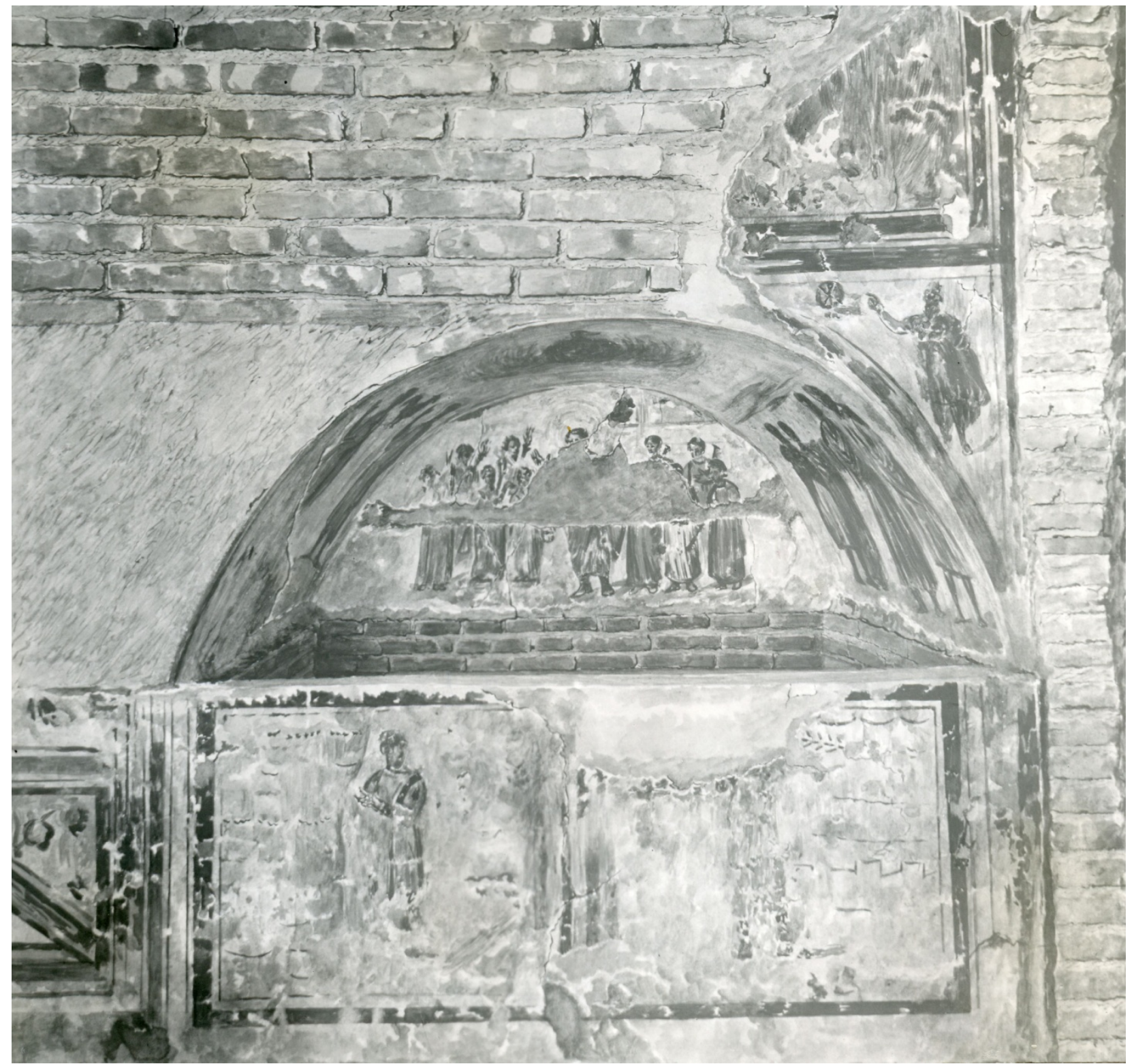

Figure 6. Arcosolium painting. San Lorenzo catacombs. Rome. 4th century (the right to publish a photo was obtained from Vatican archive). 


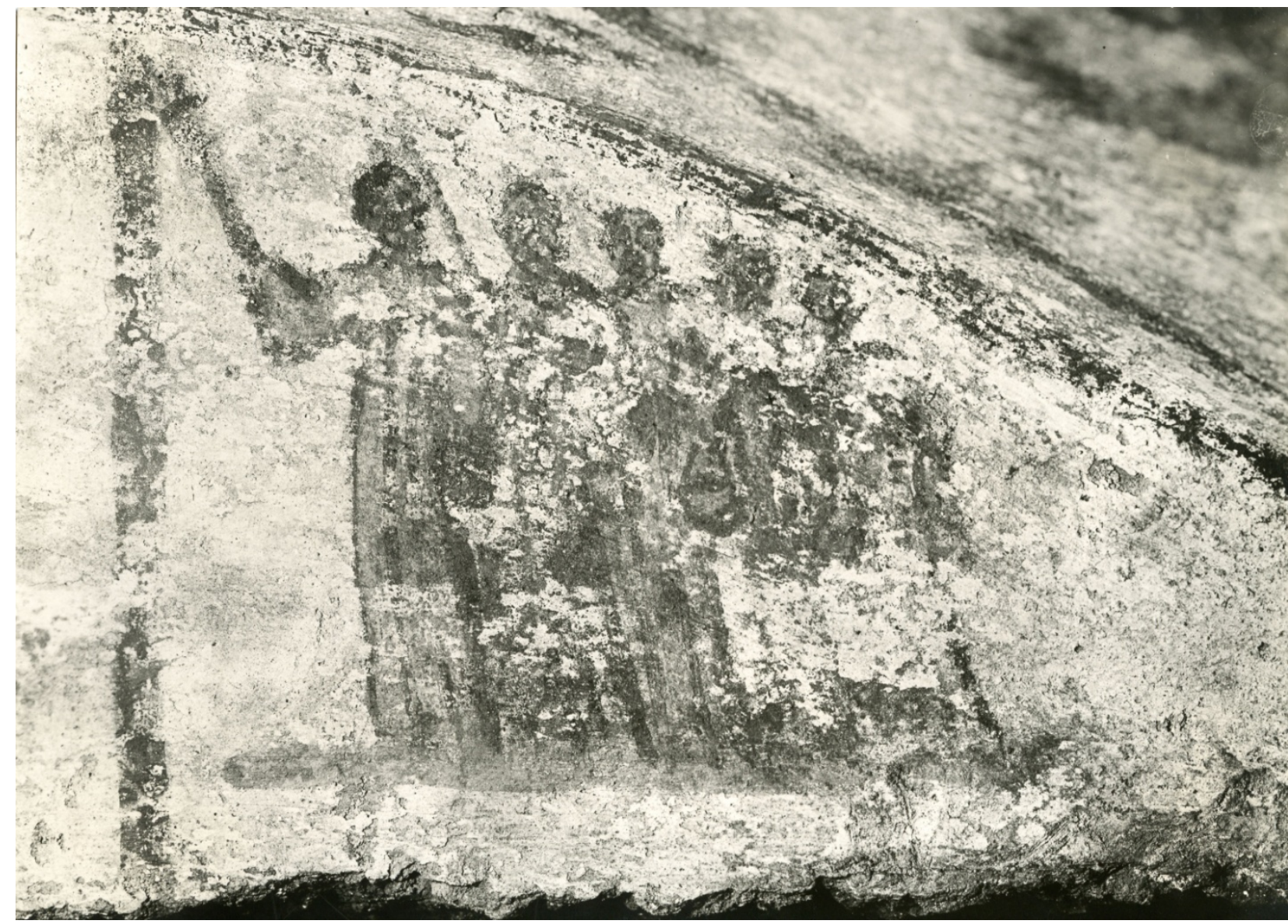

Figure 7. Arcosolium painting. Coemeterium Maius catacombs. Rome. 4th century (the right to publish a photo was obtained from Vatican archive).

\section{Conclusions}

It seems plausible that the artists had never seen a sample of procession scene to copy. Such episodes were not depicted on pieces of the decorative art such as clay vessels, or golden glass. Judging by unconventional iconography of Noah in his Arc and Adam and Eve episodes, they did not have an illustrated copy of the Bible either. The authors might have relied on their own visual experience (contemporary popular worship rituals), though hardly those of the Orthodox Early Christian tradition. The hypothesis of the shared visual experience could explain the fact that semantically different stories were depicted in a similar way. Despite the fact that the procession scene in the Chapel of Exodus is rather likely to represent the Parable of the Ten Women, it may as well be a symbolic illustration of some Early Christian legend or refer to particular historical events pertaining to the customer's life.

\section{References}

Bisconti, F. (2003). Il restauro dell'ipogeo di via Dino Compagni: Nuove idee per la lettura del programma decorative del cubicolo A (The restoration of the Dino Compagni Hypogeum: New Ideas for interpretation of the Decorative Program of the Cubiculum A). In Scavi e Restauri pubblicati a cura della PCAS, 4 (Excavations and Restorations publisherd under ther auspice of the Pontifical Commission for Sacred Archaeology). Citta del Vaticano. 
Bock, W. (1901). Matériaux pour servir à l'archéologie de l'Égypte chrétienne (Archaeological Materials of the Christian Egypt). St. Pétersbourg.

Cipriano, G. (2008). El-Bagawat. Un cimitero paleocristiano nell'alto Egitto (Al-Bagawat. An Early Christian necropolis in the Upper Egypt). Tau Editrice.

Davis, S. J. (2001). The cult of St. Thecla: A tradition of women's piety in late antiquity. Oxford: Oxford University Press.

Delehaye, H. (1903). La passion de saint Théodote d'Ancyre (The Passion of Saint Theodor of Ancyra). Analecta Bollandiana, 22, 320-328.

Grabar, A. (1956). La fresque des saintes femmes à Doura Europos (The fresco of the Saint Women in Dura Europos). Cahiers Archéologiques (Archaeological Notebooks), 8, 9-26.

Grabar, A. (1968). Early Christian art from the rise of Christianity to the death of Theodosius. New York: Odyssey Press.

Martin, M. J. (2006). Observations on the paintings of the Exodus Chapel, Bagawat Necropolis, Kharga Oasis, Egypt. In J. Burke (Ed.), Byzantine narrative. Papers in honor of Roger Scott (pp. 248-249). Melbourne: Australian Association for Byzantine Studies.

Millet, G. (1956). Doura et El-Bagawat. La parabole des vierges (Dura and Al-Bagawat. The parable of the Virgins). Cahiers Archéologiques (Archaeological Notebooks), 8, 1-8.

Peppard, M. (2012). Illuminating the Dura Europos Baptistery: Comparanda for the female figures. Journal of the Early Christian Studies, 20(4), 543-574.

Schwartz, J. (1962). Nouvelles études sur des fresques d'El-Bagawat (The New Studies on the Frescoes of Al-Bagawat). Cahiers Archéologiques (Archaeological Notebooks), 13, 1-11.

Stern, H. (1960). Les peintures du mausolée de L'Exode a El'Bagawat (The Paintings of the Exodus Mausoleum at Al-Bagawat). Cahiers Archéologiques (Archaeological Notebooks), 11, 93-119.

Thérel, M. L. (1969). La composition et le symbolisme de l'iconographie du mausolée de l'Exode a El'Bagawat (The composition and the symbolism of iconography of the Exodus Mausoleum at Al-Bagawat). Rivista Archaeologica Christiana (Christian Archaeology Review), 45, 223-270.

Weitzmann, K. (1971). The illustration of Septuagint. In H. L. Kessler (Ed.), Studies in classical and Byzantine manuscript illumination (pp. 69-75). Chicago: University of Chicago Press.

Zibawi, M. (2005). L'Oasi egiziana di Bagawat. Le pitture paleocristiane (Egyptian Oasis of Bagawat. The Early Christian paintings). Milano: Jaca Book. 